\title{
ANÁLISE DO TERRITÓRIO NORMADO PELAS UNIDADES DE CONSERVAÇÃO NO BRASIL
}

\author{
ANALYZING THE TERRITORY REGULATED BY \\ THE PROTECT AREAS IN BRAZIL \\ ANALISIS DEL TERRITORIO NORMADO DE \\ LAS UNIDADES DE CONSERVACIÓN EM BRASIL
}

\begin{abstract}
Alexandre Resende Tofeti
Doutorando em Geografia pela Universidade de Brasília. Universidade de Brasília, Departamento de Geografia - IH. Campus Universitário Darcy Ribeiro. Asa Norte 70910-900 - Brasília, DF - Brasil

e-mail: tofeti@unb.br
\end{abstract}

\section{Neio Campos}

Doutor em Planejamento Urbano e Regional pela Universidade Federal do Rio de Janeiro. Professor do Departamento de Geografia/Instituto de Ciências Humanas. Universidade de Brasília, Departamento de Geografia - IH. Campus Universitário Darcy Ribeiro. Asa Norte. 70910-900 - Brasília, DF - Brasil e.mail:neiocamp@unb.br

\section{RESUMO}

O paradoxo entre a eficiência das unidades de conservação (UC) em barrar o desmatamento e sua fragilidade institucional foi motivador para a análise aqui empreendida. É sabido que as UC historicamente são vulneráveis por falta de recursos para a sua gestão, mas são eficazes na contenção do desmatamento. Isso demonstra uma lacuna de conhecimento a ser investigado atinente às transformações territoriais que uma UC promove ao ser criada. Parte da explicação é alcançada pela análise do território normado por essa política pública. Assim, o objetivo desse artigo é promover uma análise do conjunto de normas que regem o funcionamento das UC no âmbito federal à luz de suas transformações territoriais. Ao final da análise, percebeu-se que a explicação para o paradoxo está nas normas de comando e controle; nas normas que instituem penalidades; e nas consultas públicas que informam a comunidade local sobre as consequências da criação de uma UC em um dado território.

Palavras-chave: Unidades de conservação; território normado; transformações territoriais. 


\begin{abstract}
The paradox between how efficient Protect Areas (PAs) have proved to be in deterring deforestation and their institutional weakness has motivated the analysis submitted in this paper. It is widely known that PAs are historically rendered vulnerable by their lack of management resources, but for all that they are efficient in deterring deforestation, thereby conducing to a knowedge gap to be investigated regarding territorial transformations by a PA upon creation. The explanation thereof is partwise produced by the analysis of the territory regulated by this public policy. Thus this paper aims at analyzing the rules in force about PAs at the federal level considering territorial transformations. In conclusion, this analysis shows that the explanation for the above paradox is found in command-and-control rules, in penalty-instituting rules and likewise in public consultations that inform local communities about the consequences arising out of setting up a PA in the territory.
\end{abstract}

Keywords: Protected Areas, Regulated Territory, Territory transformation.

\title{
RESUMEN
}

La paradoja entre la eficiencia de las unidades de conservación (UC) em detener la deforestación y la fragilidad institucional fue motivante para el análisis realizado aquí. Se sabe que las UC son historicamente vulnerables debido a la falta de recursos para su gestión, pero son eficaces em La contención de la deforestación. Esto demuestra una falta de conocimiento que necesita una investigación em lo que se refiere a las transformaciones territoriales que se promueve cuando una UC es creada. Parte de La explicación se logra mediante La analisis del territorio normado por esta política pública. El objetivo de este artículo es el de promover una análisis del conjunto de normas que rigen el funcionamiento de la UC em el nivel federal considerando las transformacion es territoriales. Después de La análisis, se diocuenta de que la explicación de la paradoja son las normas de comando y control; las normas que imponen sanciones; y las consultas públicas para informar a la comunidad local sobre las consecuencias de este acto de crear una UC em el territorio.

Palabras clave: Unidades de Conservación, Territorio Normado, TransformacionesTerritoriales 


\section{INTRODUÇÃO}

Uma das grandes lacunas relacionada aos estudos das unidades de conservação no Brasil são as transformações territoriais imediatas a partir do ato de assinatura de sua criação. A literatura específica sobre esse assunto mostra que as Unidades de Conservação (doravante UC) têm grande eficiência no controle do desmatamento, a despeito de sua precária estrutura de implementação. Relatório de auditoria do TCU de 2014 indica que apenas 6\% do desmatamento ocorrido na Amazônia, entre 2008 e 2012, tiveram lugar dentro de UC (BRASIL, 2014).

Em outro estudo, restou demonstrado que as UC de uso restrito conservam a natureza de modo mais eficaz que aquelas de uso sustentável. Porém, ambas restringem o desmatamento se comparadas com as áreas circundantes não contempladas com proteção legal. (SALMONA et al., 2009).

A lacuna está relacionada a um possível paradoxo entre a eficiência em alterar/barrar o padrão de ocupação associado ao desmatamento e a fragilidade institucional característica das UC no Brasil como um todo. O próprio relatório do TCU é enfático em apontar que, na Amazônia, as UC são frágeis no que diz respeito à disponibilidade de recursos. Existem UC de milhares de hectares com apenas um gestor ou simplesmente sem gestor para geri-las. Também na região amazônica, encontram-se UC com dimensões de tal sorte complexas - em razão de suas peculiaridades geográficas (rios, relevo e densidade das florestas) -, que não é possível sequer fazer um cercamento. Quando muito, postam-se placas em determinados pontos, a compor uma sinalização insuficiente de que se trata de uma área protegida. Apesar dessas insuficiências relativas ao gerenciamento e à demarcação das UC; o desmatamento, nessas áreas, é reduzido, se comparado às áreas em seu redor.

O caso da BR 163 é emblemático. Ao longo da década de 2000, com a perspectiva de pavimentação dessa rodovia, foram criadas várias UC nas imediações da rodovia entres os estados do Mato Grosso e Pará. Segundo texto explicativo consignado na página do Plano de Prevenção e Controle do Desmatamento na Amazônia Legal (PPCDAm), que está em sua $3^{\text {a }}$. fase, entre os anos de 2004 e 2008, um dos principais motivos para a drástica redução do desmatamento nesse bioma foi a criação de mais de 25 milhões de hectares de UC ${ }^{1}$. É sabido, no entanto, que boa parte dessas UC ainda hoje operam precariamente no que concerne à infraestrutura de apoio e à equipe de gestão. Como explicar, então, que uma dinâmica territorial de apropriação de recursos naturais sofra alteração profunda com o advento de uma UC?

Fonte: http://www.mma.gov.br/florestas/controle-e-preven\%C3\%A7\%C3\%A3o-do-desmatamento/plano-de-a\%C3\%A7\%C3\%A3o-para-amaz\%C3\%B4nia-ppcdam. Acessado em: 21/12/2015. 
Parte da explicação pode estar na estrutura normativa que rege a política de criação das UC e seus impactos territoriais. A título de ilustração, segundo levantamento realizado pelo Instituto Brasileiro de Planejamento e Tributação (INPT), desde a promulgação da atual Constituição Federal (05 de outubro de 1988) já foram editadas mais de 5,2 milhões de normas. Isso significa que são produzidas 532 normas por dia. ${ }^{2}$

Esse fato reforça a necessidade de, em qualquer estudo geográfico que pretenda averiguar a totalidade de algum fenômeno territorial, levar em consideração a produção normativa como hipótese explanatória. Moraes (2005), ao corroborar esse ponto de vista e utilizar os pressupostos fundantes da abordagem do materialismo histórico e dialético, afirma que "[...] a estruturação da sociedade define a relação dos indivíduos com a maior parte dos recursos naturais, ao normatizar as suas relações entre si." (p. 75). Nesse sentido, o objetivo desse artigo é promover uma análise do rol de normas que regem o funcionamento das UC no âmbito federal à luz de suas transformações territoriais, considerando que os sistemas estaduais ou até municipais são em geral espelhos da esfera federal. Pretende-se, ao final dessa análise, demonstrar por qual motivo as UC desestruturadas de pessoal e de infraestrutura não são alvo das práticas antrópicas incidentes em áreas circundantes. Eis o paradoxo alvo deste artigo.

\section{METODOLOGIA}

O procedimento de análise adotado inicial foi o levantamento de normas relativas ao Sistema de Unidades de Conservação feito pelo relatório de auditoria do TCU, citado anteriormente (Figura 1) ${ }^{3}$. Esse levantamento, até o arremate deste trabalho, foi o mais exaustivo possível, razão pela qual será utilizado como base. Além disso, para evitar um exame eminentemente jurídico, o que fugiria da proposta deste artigo, divide-se a análise em normas de impacto imediato e mediato no território.

\footnotetext{
2 Fonte: http://www.ibpt.com.br/img/uploads/novelty/estudo/2272/QuantidadeDeNormas201527 AnosCF01102015.pdf. Acessado em: 21/12/2015.

3 Não se ignora que as normas, principalmente no Brasil, sofrem modificações constantes. De todo modo, esse levantamento presta-se a configurar o cenário normativo da área sob investigação neste trabalho.
} 


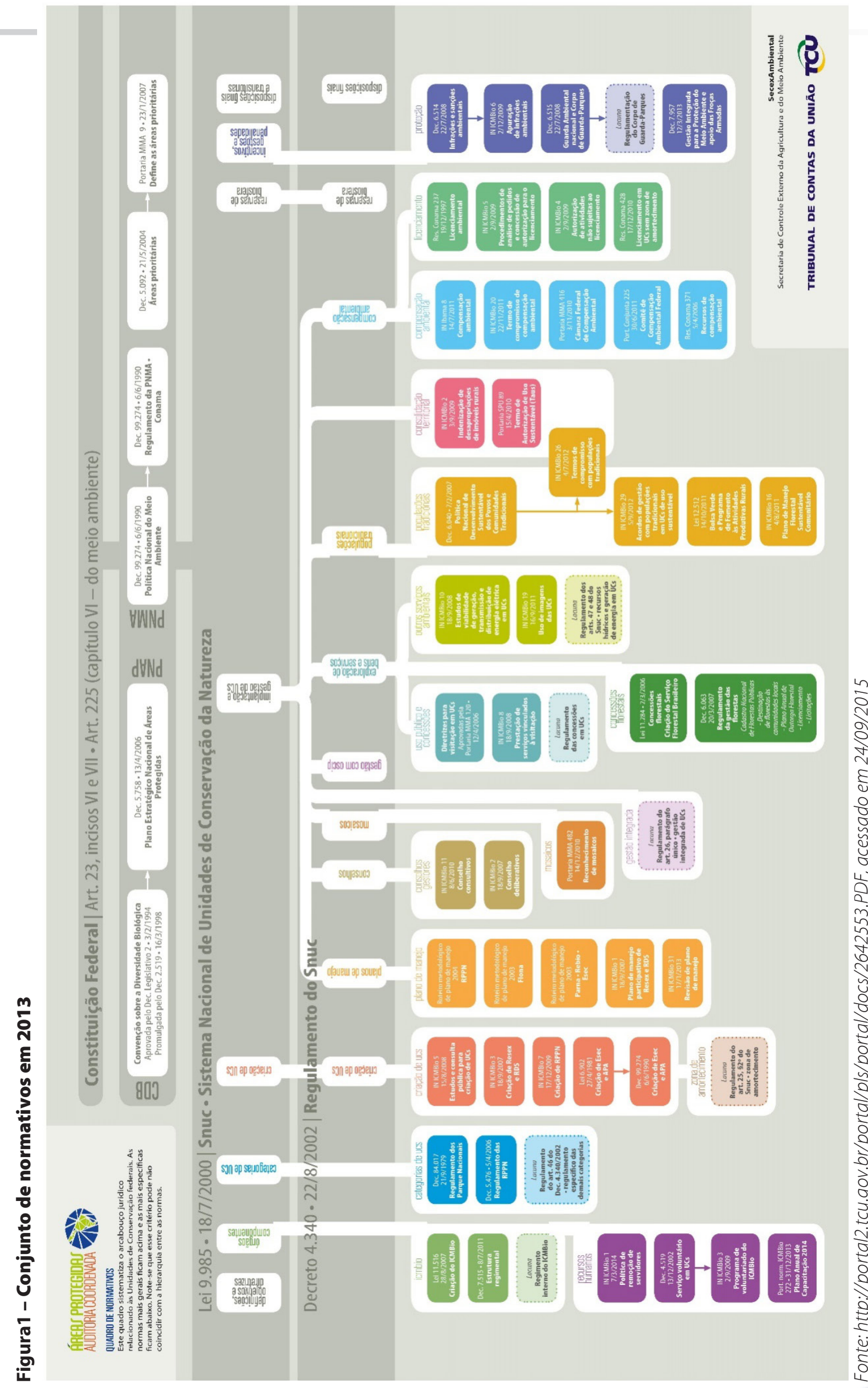

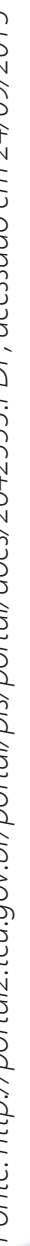

U $\underset{\infty}{\times}$ ง 르 反 ช $+$ n u 
Utilizar-se-á como premissa a proposta conceitual do termo território desenvolvida por Santos em seu percurso erudito. Segundo Moraes (2013), esse conceito foi ganhando envergadura teórica ao longo da trajetória intelectual daquele pensador. De início, o conceito estava vinculado apenas às unidades político-administrativas, para, posteriormente, incorporar uma visão mais dinâmica de espaço de circulação e fluxo de materiais. Um momento diferencial nessa trajetória de aprofundamento dessa categoria perfez-se quando a distinguiu como materialidade e "a configuração territorial como uso social e historicamente definido desse âmbito espacial" (MORAES, p.14). Por fim, as derradeiras obras de Santos, segundo Moraes, enfatizam que "é o próprio território que incorpora em si sua possibilidade de uso, com a formulação do conceito de 'território usado"' (Ibidem, p. 14).

Conforme observou Steinberger (2013), também baseada na leitura da obra de Santos,

O território não é apenas material. É simultaneamente material e social. [...] não é propriedade do estado e sim de todos os agentes e atores sociais que têm poder do 'agir político' na sociedade. [...] não é mero recipiente morto que abriga a ação do Estado. [...] é ativo e essa atividade está no uso que os agentes e atores sociais fazem dele. (STEINBERGER, p. 63)

Em complemento, o autor em apreço afirma que o território é a materialidade e o espaço é a materialidade e a vida que a anima (SANTOS, 2002). Defende também que "o território são formas, mas o território usado são objetos e ações” (SANTOS, 1996, p.16)

Para finalizar a delimitação dos pressupostos teóricos da metodologia; cumpre citar outra passagem de Santos na qual afirma que:

A formação social nacional funciona, pois, como uma mediação entre o Mundo e a Região, o Lugar. Ela é, também, mediadora, entre o Mundo e o Território. Mais do que a formação socioeconômica é a formação socioespacial que exerce esse papel de mediação: este não cabe ao território em si, mas ao território e seu uso, num momento dado, o que supõe de um lado uma existência material de formas geográficas, naturais ou transformadas pelo homem, formas atualmente usadas e, de outro lado, a existência de normas de uso, jurídicas ou meramente costumeiras, formais ou simplesmente informais. [...] Formas e normas, pois, trabalham como um conjunto indissociável. [...] o território nacional, ou local, é, em sim mesmo, uma norma, função de sua estrutura e de seu funcionamento. [...] O universal é o Mundo como Norma, uma situação não-espacial, mas que cria e recria espaços locais; o particular é dado pelo país, isto é, o território normado; e o individual é o lugar, o território como norma. (SANTOS, 2002, p. 336-338)

A partir desses fundamentos conceituais, pode-se ponderar que as normas afetam a materialidade e o seu funcionamento (os usos inerentes à materialidade). No entanto, pondera-se que existem normas geradoras de efeitos imediatos ao território e aquelas de efeito mediato. As imediatas comprometem de pronto a materialidade ou o uso correlato. Por esse motivo, assume-se que as normas de efeito imediato são as que, provavelmen- 
te, mais subsidiarão a explicação da problemática paradoxal inquirida neste trabalho. Por exemplo, normativos de criação de uma UC são considerados de impacto imediato no território, pois destacam uma materialidade que passará a ter novos usos. Em contrapartida, existem normas regentes do funcionamento das UC que, em alguns casos, impactam indiretamente o território; são as de efeito mediato. Por exemplo, normas que indicam o fluxo burocrático relativo à gestão, de modo geral, impactam indiretamente o território. Considera-se, então, como hipótese que as de impacto imediato são as que mais promovem a regressão dos usos pretéritos.

\section{A ANÁLISE}

É importante destacar que a análise a seguir não diz respeito à eficácia das normas ou ao seu grau de implementação, mas sim apenas ao potencial de alteração do território previsto no normativo a partir do entendimento do conceito de território e do território usado.

De início, destaca-se que existem normas gerais que emprestam pressupostos e diretrizes para a formulação das normas específicas sobre a temática das UC. Essas normas estão destacadas na parte superior da Figura 1: a Constituição Federal, Art. 23, incisos VI e VII e Art. 225. O Decreto n. 2.519/1998, que promulga a Convenção sobre Diversidade Biológica; o Decreto n ${ }^{\circ}$. 5.758/2006, que estabelece o Plano Estratégico Nacional de Áreas Protegidas; a Lei no. 6.938/1981, que instituiu a Política Nacional de Meio Ambiente; o Decreto $n^{\circ} .5 .092 / 2004$, que define os critérios e procedimentos para eleger áreas prioritárias; e a Portaria/MMA no. 09/2007, que define as áreas prioritárias para a conservação, utilização sustentável e repartição de benefícios da biodiversidade brasileira.

Embora esse conjunto de normas não defina ações específicas; elas são orientadoras para uma série de ações programáticas. É importante destacar que de toda norma emanam ações ou orientações. Aquelas que têm um caráter orientativo geral são classificadas como de efeito mediato ao território. Aquelas que, de alguma maneira, criam formas sobre o território ou indicam onde criá-las e também aquelas que indicam, de modo categórico, o conteúdo das formas e as ações delas diretamente decorrentes são classificadas como de efeito imediato. É possível afirmar que parte do conteúdo das formas territoriais é determinada pelas normas. Por exemplo, são as normas que determinam como um dado território será demarcado como área residencial, comercial, própria para os usos nas UC, etc.

Steinberger (2013), a partir da leitura da obra de Milton Santos, elucida bem esse conceito de formas-conteúdo a respeito do qual se está tratando aqui. Segundo a autora, 
[...] Milton Santos mostra que as formas espaciais exercem o papel de "atrizes" em cada momento histórico de uma formação socioespacial. Explica que esse papel está ligado não só ao valor dos objetos geográficos enquanto "herança de um modo de produção passado", mas ao valor atual destes objetos como conteúdo novo e real, atribuído pelas formas, em um modo de produção presente, "porém como forma-conteúdo". Tal explicação [...] nos permite entender que as formas espaciais são formas-conteúdo porque os objetos geográficos que as representam ganham valor ao longo do tempo histórico. (STEINBERGER, 2013, p. 39)

Assim, a Constituição Federal e os Decretos nº. 2.519/1998 e nº. 5.758/2006, em geral, são normas de caráter mediato no tocante ao aspecto territorial. A título de exemplo, os dois decretos tratam dos seguintes temas em linhas gerais: promover o manejo sustentável dos recursos naturais das UC, bem como implementar os Planos de Manejo; buscar a representatividade de UC por bioma; promover a educação ambiental e a capacitação; envolver o entorno da UC e os diferentes atores na gestão; promover a consolidação territorial das UC e reduzir incêndios, a biopirataria e controlar os cultivos na UC e em sua Zona de Amortecimento; entre outros. Como pode ser notado, são diretrizes para a ação. É bom lembrar, também, que são normas que tratam de modo geral da conservação da biodiversidade, e não especificamente de UC.

Destaca-se desse conjunto inicial o Decreto no. 5.092/2004 e a Portaria no. MMA 09/2007, pois, a princípio, orientam onde devem ser criadas novas formas no território relacionadas àsUC. Esses dois normativos resultaram em um grande esforço encabeçado pelo MMA para definir as áreas prioritárias, bem como o grau de necessidade de conservação da biodiversidade. É um claro indicativo de onde devem ser criadas UC no território nacional. Mais uma vez, não é a ação propriamente dita de criar uma forma no território, mas uma referência para tal, portanto é uma norma de efeito mediato.

Em 2007, houve outro grande esforço liderado pelo MMA para atualizar a lista de áreas prioritárias à luz dos novos conhecimentos gerados (BRASIL, 2007). Por ocasião da edição desse instrumento normativo, geraram-se alguns números, a saber:

a. em 2004, havia 900 áreas prioritárias, as quais se ampliaram para 2.683, sendo que dessas, 1.123 são áreas protegidas na forma de UC ou Terras Indígenas;

b. a Mata Atlântica conta com 880 áreas prioritárias, seguida da Amazônia com 824, o Cerrado com 431, a Caatinga com 292, o Pampa com 105, a Zona Marinha com 102 e o Pantanal com 50 completa a lista.

O aumento do número de áreas prioritárias é apontado como reflexo da melhoria da quantidade e qualidade dos dados disponíveis; aperfeiçoamento da metodologia; e apoio proativo da sociedade para indicar, de modo empírico, as pressões e bolsões de biodiversidade (BRASIL, 2007). 
Novamente com base na Figura 1, a observar um subnível de análise, alcança-se a Lei $n^{\circ}$. 9.985, de 18 de julho de 2000, que instituiu o Sistema Nacional de Unidades de Conservação (SNUC); e o Decreto nº 4.340, de 22 de agosto de 2002, que regulamenta alguns dispositivos do SNUC. Pode-se afirmar que esses dois normativos são a essência das UC e que, de fato, definem o conteúdo da forma UC. Por esse motivo, são de impacto imediato ao território.

O SNUC possui prolegômenos relacionados a conceitos, objetivos e diretrizes tomados emprestados das leis supracitadas. O que interessa são os tipos de unidades de conservação criadas por essa norma, pois cada tipo definirá os usos e não usos permitidos dentro dos limites das UC. São duas as categorias de UC definidas na lei:

As Unidades de Proteção Integral: Estação Ecológica, Reserva Biológica, Parque Nacional, Monumento Natural e Refúgio de Vida Silvestre.

As Unidades de Uso Sustentável: Área de Proteção Ambiental, Área de Relevante Interesse Ecológico, Floresta Nacional, Reserva Extrativista, Reserva de Fauna, Reserva de Desenvolvimento Sustentável e Reserva Particular do Patrimônio Natural.

O traço em comum a todas as formas de UC definidas são as paisagens de vegetação natural relativamente preservadas. Em outras palavras, as formas das UC são, em geral, a vegetação dos diferentes biomas ou belezas cênicas não criadas pelo homem. O conteúdo dessas formas vai variar a depender do tipo de UC, pois cada uma possui um rol de proibições ou permissões. Logo, reforça-se que o uso e não uso definem o conteúdo da forma.

Por exemplo, o Parque Nacional da Tijuca está encravado no meio da segunda maior cidade brasileira, o Rio de Janeiro. Sua forma predominante é vegetação de mata atlântica entremeada por um relevo movimentado de morros e montanhas. Além disso, apresenta trilhas, infraestrutura de lazer e passeios. Seu conteúdo consiste basicamente na atividade de turismo, lazer e contemplação, proibido qualquer tipo de extrativismo.

Para analisar melhor a norma em termos de impacto no território é importante deter-se em cada tipo de UC. Para tanto, os Quadros 1 e 2 a seguir sintetizam as características principais de cada UC. 
Quadro 1 - Comparativo entre unidades de conservação de Proteção Integral.

\begin{tabular}{|c|c|c|c|c|c|}
\hline \multicolumn{6}{|c|}{ UNIDADES DE PROTEÇÃO INTEGRAL } \\
\hline Usos e caracteristicas da UC & Estação Ecológica & Reserva Biológica & Parque Nacional & Monumento Natural & Refúgio da Vida Silvestre \\
\hline $\begin{array}{l}\text { Objetivos principais da } \\
\text { conservação }\end{array}$ & pesquisa & pesquisa e educação & pesquisa e educação & $\begin{array}{c}\text { conservação, } \\
\text { especialmente de beleza } \\
\text { cênica, pesquisa e } \\
\text { educação }\end{array}$ & pesquisa e educação \\
\hline $\begin{array}{l}\text { Processo de criação } \\
\text { nomalmente iniciado por }\end{array}$ & governo & governo & governo & governo & governo \\
\hline Posse de terras & pública & pública & pública & pública e privada & pública e privada \\
\hline $\begin{array}{l}\text { Compatível com presença } \\
\text { de moradores }\end{array}$ & não & não & não & $\operatorname{sim}$ & $\operatorname{sim}$ \\
\hline $\begin{array}{l}\text { Processo de regularização } \\
\text { inclui desaproriação de terra? }\end{array}$ & $\operatorname{sim}$ & $\operatorname{sim}$ & $\operatorname{sim}$ & & \\
\hline Conselho Gestor & consultivo & consultivo & consultivo & consultivo & consultivo \\
\hline Mineração permitida? & não & não & não & não & não \\
\hline $\begin{array}{l}\text { Instrumento de gestão } \\
\text { ordinários }\end{array}$ & $\begin{array}{l}\text { planejo de manejo, } \\
\text { aprovado e publicado } \\
\text { pelo órgão gestor }\end{array}$ & $\begin{array}{l}\text { planejo de manejo, } \\
\text { aprovado e publicado } \\
\text { pelo órgão gestor }\end{array}$ & $\begin{array}{l}\text { planejo de manejo, } \\
\text { aprovado e publicado } \\
\text { pelo órgão gestor }\end{array}$ & $\begin{array}{l}\text { planejo de manejo, } \\
\text { aprovado e publicado } \\
\text { pelo órgão gestor }\end{array}$ & $\begin{array}{l}\text { planejo de manejo, } \\
\text { aprovado e publicado } \\
\text { pelo órgão gestor }\end{array}$ \\
\hline Realização de pesquisas & $\begin{array}{l}\text { depende de aprovação } \\
\text { prévia do órgão gestor }\end{array}$ & $\begin{array}{l}\text { depende de aprovação } \\
\text { prévia do órgão gestor }\end{array}$ & $\begin{array}{l}\text { depende de } \\
\text { aprovação prévia do } \\
\text { órgão gestor }\end{array}$ & $\begin{array}{l}\text { depende de aprovação } \\
\text { prévia do órgão gestor }\end{array}$ & $\begin{array}{l}\text { depende de aprovação } \\
\text { prévia do órgão gestor }\end{array}$ \\
\hline
\end{tabular}

Fonte: http://uc.socioambiental.org/o-snuc/quadro-comparativo-das-categorias, acessado em 24/02/2016.

As UC do Quadro 1 apresentam uma restrição maior de uso em seu interior. É possível observar que essas formas atendem apenas aos interesses de pesquisa, educação e recreação, sendo a mais restritiva a Estação Ecológica, e as mais permissivas Monumento Natural e Refúgio da Vida Silvestre. Essa observação é relativa às ações para dentro da UC. 
Uma segunda observação sobre essa categoria de UC diz respeito à presença marcante do ente governamental. Quem cria é o Estado, a posse privada não é permitida na maioria das UC, o conselho gestor tem caráter apenas consultivo, a realização de pesquisa depende de manifestação do órgão gestor e o plano de manejo também depende de aprovação e publicação pelo mesmo órgão. Não por coincidência essas UC são adotadas pelo governo como uma estratégia de comando e controle sobre os usos e a ocupação do território.

Uma terceira observação diz respeito às transformações territoriais para fora dos limites das UC. Uma das ações que mais repercute com o entorno da UC são os planos de manejo e a instituição dos Conselhos Consultivos, que, de fato, mobilizam atores ao redor da UC. Embora de caráter apenas consultivo, o conselho promove reuniões para discutir questões afetas ao território, sem paralelo no Brasil ${ }^{4}$. Se considerarmos a situação pretérita à criação da UC, não existia medida parecida capaz de reunir, em uma mesma mesa de discussão e negociação, um conjunto díspar de atores interessados no mesmo território. O plano de manejo, por seu turno, presta-se a orientar a gestão da UC, com ações para dentro e para fora da sua área. Um exemplo concreto ilustrativo da influência externa à UC gerada por força de seus órgãos e instrumentos normativos, cujo delineamento será aprofundado mais à frente, diz respeito às zonas de amortecimento, cujos usos devem ser referenciados no plano de manejo.

Como última observação quanto a esse tipo de UC, cabe destacar as Estações Ecológicas, as Reservas Biológicas e os Parques Nacionais, pois são as mais restritivas. É de se supor que essas UC, ao serem criadas, têm grande impacto em territórios ocupados antes de sua criação, visto que, como essas terras são exclusivamente públicas, não se permite a presença de moradores. Via de consequência, ocorrem desapropriações, com a permissão de uso indireto dos recursos naturais. Em contrapartida, quando são criadas em território pouco antropizado e de baixa ocupação, como em algumas áreas da Amazônia, suas transformações e impactos territoriais tendem a ser de menor grau. Resta claro, assim, que uma análise sobre as transformações territoriais das UC no território brasileiro deve levar em conta as condições territoriais anteriores ao ato de criação.

Em suma, as quatro observações permitem concluir que os artigos respectivos da lei que tratam desses tipos de UC apresentam, essencialmente, impacto imediato no território quando se desencadeia o ato de sua criação.

${ }_{4}$ Não se desconhecem outros fóruns criados para discutir questões municipais territoriais,tais como as consultas públicas obrigatórias sobre os planos diretores municipais, mas esses fóruns são temporários e de fraca institucionalidade. 
Quadro 2 - Comparativo entre unidades de conservação de Uso Sustentável.

\begin{tabular}{|c|c|c|c|c|c|c|c|}
\hline \multicolumn{8}{|c|}{ Unidades de Uso Sustentável } \\
\hline $\begin{array}{c}\text { Usos e características da } \\
\text { UC }\end{array}$ & Floresta & Reserva Extrativista & $\begin{array}{c}\text { Reserva de } \\
\text { Desenvolvimento } \\
\text { Sustentável }\end{array}$ & Reserva de Fauna & $\begin{array}{l}\text { Área de Relevante } \\
\text { Interesse Ecológico }\end{array}$ & Área Proteção Ambiental & RPPN \\
\hline $\begin{array}{l}\text { Objetivos principais além } \\
\text { da conservação }\end{array}$ & $\begin{array}{c}\text { pesquisa e produção de } \\
\text { madeireiros e não } \\
\text { madeireiros de espécies } \\
\text { nativas }\end{array}$ & $\begin{array}{c}\text { proteção dos meios de } \\
\text { vida e cultura da } \\
\text { comunidade tradicional e } \\
\text { uso sustentável dos } \\
\text { recursos } \\
\end{array}$ & \begin{tabular}{|c|} 
proteção dos meios de \\
vida e cultura da \\
comunidade tradicional e \\
uso sustentável dos \\
recursos
\end{tabular} & $\begin{array}{c}\text { pesquisas técnico- } \\
\text { cientificas sobre manejo } \\
\text { das espécies }\end{array}$ & $\begin{array}{c}\text { conservaçao de relevância } \\
\text { regional, normalmente } \\
\text { áreas com baixa ocupação } \\
\text { humana }\end{array}$ & $\begin{array}{l}\text { ordenamento territorial, } \\
\text { normalmente áreas com } \\
\text { ocupação humana } \\
\text { consolidada }\end{array}$ & $\begin{array}{l}\text { pesquisa, educação e } \\
\text { ecoturismo }\end{array}$ \\
\hline $\begin{array}{l}\text { Processo de criação } \\
\text { normalmente iniciado por }\end{array}$ & governo & comunidade & governo & governo & governo & governo & proprietário \\
\hline Posse de terras & $\begin{array}{c}\text { pública com concessão de } \\
\text { real de uso para a } \\
\text { comunidade }\end{array}$ & $\begin{array}{c}\text { pública com concessão de } \\
\text { real de uso para a } \\
\text { comunidade }\end{array}$ & \begin{tabular}{|c|} 
pública com concessão de \\
real de uso para a \\
comunidade e privada \\
\end{tabular} & pública & pública e privada & pública e privada & privada \\
\hline $\begin{array}{l}\text { Compatível com } \\
\text { presença de moradores? }\end{array}$ & $\begin{array}{l}\text { sim, populações } \\
\text { tradicionais }\end{array}$ & $\begin{array}{l}\text { sim, populações } \\
\text { tradicionais }\end{array}$ & $\begin{array}{l}\text { sim, populações } \\
\text { tradicionais }\end{array}$ & $\operatorname{sim}$ & $\operatorname{sim}$ & $\operatorname{sim}$ & $\operatorname{sim}$ \\
\hline $\begin{array}{l}\text { Processo de } \\
\text { regularização inclui } \\
\text { desapropriaçöes de } \\
\text { terra? }\end{array}$ & sim & $\operatorname{sim}$ & $\begin{array}{c}\text { não obrigatoriamente, } \\
\text { apenas se o uso privado } \\
\text { não for considerado } \\
\text { compativel com o } \\
\text { propósito da UC } \\
\end{array}$ & $\operatorname{sim}$ & $\begin{array}{l}\text { não obrigatoriamente, } \\
\text { apenas se o uso privado } \\
\text { não for considerado } \\
\text { compativel com o } \\
\text { propósito da UC }\end{array}$ & $\begin{array}{l}\text { não obrigatoriamente, } \\
\text { apenas se o uso privado } \\
\text { não for considerado } \\
\text { compativel com o } \\
\text { propósito da UC }\end{array}$ & não \\
\hline Conselho Gestor & consultivo & deliberativo & deliberativo & $\begin{array}{l}\text { não há restrições, } \\
\text { usualmente consultivo }\end{array}$ & $\begin{array}{l}\text { não há restrições, } \\
\text { usualmente consultivo }\end{array}$ & $\begin{array}{l}\text { não há restrições, } \\
\text { usualmente consultivo }\end{array}$ & $\begin{array}{c}\text { não há, mas em caso de } \\
\text { serem localizadas em } \\
\text { mosaico de áreas } \\
\text { protegidas, o proprietário } \\
\text { tem direito a uma cadeira } \\
\text { no Conselho do mesmo }\end{array}$ \\
\hline Mineração permitida? & $\operatorname{sim}$ & não & $\operatorname{sim}$ & - & - & - & não \\
\hline $\begin{array}{l}\text { Instrumentos de gestão } \\
\text { ordinários }\end{array}$ & $\begin{array}{c}\text { plano de manejo, } \\
\text { aprovado pelo conselho e } \\
\text { pelo órgão gestor, plano } \\
\text { de uso e contrato de } \\
\text { concessão florestal }\end{array}$ & $\begin{array}{c}\text { plano de manejo, } \\
\text { aprovado pelo conselho e } \\
\text { pelo órgão gestor e plano } \\
\text { de uso }\end{array}$ & $\begin{array}{c}\text { plano de manejo, } \\
\text { aprovado pelo conselho e } \\
\text { pelo órgão gestor e plano } \\
\text { de uso }\end{array}$ & $\begin{array}{c}\text { plano de manejo, } \\
\text { aprovado e publicado pelo } \\
\text { órgão gestor }\end{array}$ & $\begin{array}{c}\text { plano de manejo, } \\
\text { aprovado e publicado pelo } \\
\text { orgão gestor }\end{array}$ & $\begin{array}{c}\text { plano de manejo, } \\
\text { aprovado e publicado pelo } \\
\text { órgão gestor }\end{array}$ & $\begin{array}{c}\text { plano de manejo, } \\
\text { aprovado e publicado pelo } \\
\text { órgão gestor }\end{array}$ \\
\hline Realização de Pesquisas & $\begin{array}{l}\text { depende de aprovação } \\
\text { prévia do órgão gestor }\end{array}$ & $\begin{array}{l}\text { depende de aprovação } \\
\text { prévia do órgão gestor }\end{array}$ & $\begin{array}{l}\text { depende de aprovação } \\
\text { prévia do órgão gestor }\end{array}$ & $\begin{array}{l}\text { depende de aprovação } \\
\text { prévia do órgão gestor }\end{array}$ & $\begin{array}{l}\text { depende de aprovação } \\
\text { prévia do órgão gestor }\end{array}$ & - & - \\
\hline
\end{tabular}

Fonte: http://uc.socioambiental.org/o-snuc/quadro-comparativo-das-categorias, acessado em 24/02/2016. 
As UC do Quadro 2 são as de uso sustentável, as mais complexas em termos de análise das transformações no território pelo fato de possibilitarem a ocupação em seu interior. A complexidade está na seguinte questão: existe uma área, com um grau de ocupação, cujo território ainda apresenta importantes traços remanescentes de biodiversidade e cujo uso carece de maior coordenação. A meta essencial visa a manter as ocupações e regular o uso das áreas ainda não ocupadas ou pouco ocupadas. Como não envolve, de modo geral, desapropriações, têm sido as unidades de conservação mais criadas nos últimos anos. Segundo Prates \& Souza (2014), os governos federal e, principalmente, estaduais têm utilizado as Áreas de Proteção Ambiental como estratégia de inserção da política ambiental, sem embates muito comprometedores em termos políticos. Na esfera federal, $52 \%$ das UC são de uso sustentável e, na esfera estadual, 79\%; considerando que, do universo total de área ocupada por UC no Brasil, as APA correspondem a 52\%.

O território normado dessas categorias de UC é mais permissivo nos usos, ao delegar maior poder de decisão para a população local, na medida em que parte de seus conselhos tem caráter deliberativo; possui a prerrogativa de criar a UC a partir de demanda da comunidade e não só por iniciativa governamental; admite a permanência de moradores, porém, em alguns casos, há restrição de permanência exclusivamente para populações tradicionais; ostenta em seus objetivos, em geral, uma melhor regulação da relação homem-natureza.

Esses tipos de UC trazem em seus objetivos a essência do conteúdo da forma. A título de ilustração, as Florestas Nacionais (Flona), as Reservas de Desenvolvimento Sustentável (RDS) e as Reservas Extrativistas (Resex) têm como fim principal a promoção do uso sustentável dos recursos naturais contidos no local e a manutenção dos modos de vida de populações tradicionais - a Flona estimula os usos múltiplos e a pesquisa de produtos madeireiros e não madeireiros de espécies nativas; e as RDS e as Resex objetivam proteger os meios de vida e a cultura das populações que comprovadamente dependem do extrativismo como subsistência. As Áreas de Relevante Interesse Ecológico (ARIE) e as Áreas de Proteção Ambiental (APA) possuem objetivos similares relacionadas ao disciplinamento do uso do território com vistas à manutenção de remanescentes naturais relevante. A diferença capital entre elas recai no grau de ocupação e extensão das áreas: as APA são, em geral, extensas, com grau de ocupação consolidado; ao passo que as ARIE, ao contrário, são áreas de extensão diminuta, com nível de ocupação baixo. Por fim, as Reservas de Fauna possuem caráter similar às unidades de proteção integral, com a diferença de que é permitida a presença de moradores. Seu objetivo principal é a pesquisa sobre o manejo econômico sustentável de recursos faunísticos e, por isso, deve apresentar populações de 
animais de espécies nativas representativas. Também as Reserva Particulares de Patrimônio Natural apresentam perfil similar ao outro grupo de unidades de conservação, mais uma vez com o diferencial de que essas UC são criadas em propriedades particulares, a partir de demanda voluntária do proprietário.

O tipo de repercussão para dentro e para fora desse grupo de UC tem muita relação com o caráter do conselho da unidade, do seu plano de manejo e da eficiência na sua aplicação. De todo modo, a princípio, as reuniões do conselho podem ser definidoras do que ocorrerá no território a partir da constituição da unidade, principalmente se esse conselho for deliberativo. Já os planos de manejo devem indicar um zoneamento a ser seguido em seu interior, com recomendação dos usos e não usos do território. Da mesma maneira, as Resex e as RDS pressupõem a instituição de acordo de uso dos recursos naturais para manter a sustentabilidade em longo prazo. Todos esses aspectos serão alvo de aprofundamento nas próximas linhas ao se analisarem os normativos que regem o seu funcionamento.

O que importa saber é que as transformações territoriais advindas com a criação desse tipo de UC apresentam maior ou menor intensidade e impacto a depender do território na qual foi criada e do tipo de uso e de ocupação que se tinha antes da sua criação. Genericamente, as transformações territoriais tendem a ser mais sutis pelo simples fato de não se alterar ou se proibir a ocupação que já existia no território. Mesmo assim, pode-se considerar, tais como as UC de proteção integral, que os efeitos dos dispositivos legais referentes às UC de uso sustentável da lei ora em análise são de caráter imediato por conferir status diferenciado a determinados territórios, a partir da criação da forma UC.

Por fim, analisando essas duas normas mestras do sistema de unidades de conservação é possível extrair pistas para responder a dúvida instigadora desse artigo: como é possível mudar o padrão de uso e ocupação do território por meio da criação de UC com precária capacidade de gestão? No SNUC, encontra-se um capítulo que se dedica, entre outros assuntos, ao tema da consulta pública como pré-requisito para a criação de uma UC. No artigo $22^{\circ}, \$ 2^{\circ}$, explicita-se que toda criação de UC deve ser precedida de estudos técnicos e consulta pública, excetuando-se as Estações Ecológicas e Reservas Biológicas $\left(\$ 4^{\circ}\right)$. Embora existam críticas contundentes a respeito da efetividade do caráter participativo dessas consultas públicas, não deixa de ser importante destacar que esse é o primeiro meio de informar a comunidade local sobre a futura criação de UC e de suas consequências. Mais à frente, ao se analisar o normativo que regulamenta essa consulta, nova luz será dada para responder à questão central. Também no decreto regulamentador há um dispositivo legal elucidativo, qual seja, o Art.15, no bojo do qual se afirma que, no interstício entre a criação da UC e o estabelecimento do Plano de Manejo, devem ser for- 
malizadas e implementadas ações de proteção e fiscalização. Presume-se que a comunidade local, na medida em que se torna ciente dessa determinação por meio das consultas públicas, mude seu padrão de uso e ocupação do território.

Afora os tipos de UC, a Lei no. 9.985/2000 e o seu decreto regulamentador, Decreto $n^{\circ} 4.340 / 2002$, ainda tratam dos seguintes aspectos que se desdobrarão em normativos (Figura 1): órgãos componentes do SNUC; regulamentação/detalhamento de algumas categorias de UC; criação e implantação de UC; gestão das UC; incentivos, apoios auxiliares e penalidades e reservas da biosfera. As próximas linhas irão destrinçar cada um desses aspectos, mais uma vez sob o olhar das transformações que elas causam ao território.

Nesse sentido, o primeiro tema a ser tratado é a institucionalidade ${ }^{5}$ criada a partir da Lei ${ }^{\circ}$. 9.985/2000. Inicialmente, o SNUC era gerido e implementado pelo Instituto Brasileiro do Meio Ambiente e dos Recursos Naturais Renováveis (Ibama), mas, em 2007, com o intuito de fortalecer a agenda das UC, criou-se, com o objetivo similar, o Instituto Chico Mendes de Conservação da Biodiversidade (ICMBio), por meio da Lei nº. 11.516, de 28 de agosto. Em 2011, definiu-se a estrutura regimental a partir da publicação do Decreto $n^{\circ} 7.515$, de 08 de julho.

A institucionalidade criada gera formas ou afeta formas/conteúdo de outras já existentes. Explica-se: a criação do ICMBio, com sede em Brasília, demandou uma estrutura predial, conquanto não se considere como geradora de impacto imediato no território por não estar atrelada às proximidades de alguma UC. É desse órgão que emanam boa parte das ações que afetam diretamente uma UC. A menção de atribuições da autarquia federal sob exame exemplifica em parte como a institucionalidade gera formas e/ou afeta o conteúdo de tal constatação:

\section{Art. $2^{\circ}(\ldots)$}

I - propor e editar normas e padrões de gestão, de conservação e proteção da biodiversidade e do patrimônio espeleológico, no âmbito das unidades de conservação federais;

II - fiscalizar e aplicar penalidades administrativas ambientais pelo descumprimento da legislação em vigor no que tange à proteção das unidades de conservação federais e respectivas zonas de amortecimento;

III - propor ao Ministério do Meio Ambiente a criação de unidades de conservação federais; (...)

VIII - promover e executar a recuperação das áreas degradadas em unidades de conservação federais.

5 Institucionalidade no sentido do reconhecimento formal e social da importância e propriedade da norma legal. 
Os efeitos oriundos da criação da sede do ICMBio aplicam-se para todas as UC, uma vez que a institucionalidade cria formas ou afeta formas/conteúdos de outras já existentes, pois serão construídas benfeitorias para a sede da UC ou ocupar-se-á imóvel em cidade próxima para exercer essa função. Além dessas formas/conteúdo, ainda compõem a estrutura do órgão os centros regionais e centros de pesquisa e formação. O restante das duas normas diz respeito a questões de loteamento e atribuições dos diferentes cargos dessa carreira, o que não diz muito para a análise territorial empreendida aqui. Nesse sentido, esses dois normativos apresentam impacto mediato e imediato no território como exposto acima.

Por fim, a Figura 1 apresenta ainda Portarias Normativas que estabelecem os planos anuais de capacitação. Contudo, esse aspecto é bem específico, pois visa à formação e aprimoramento do quadro técnico da instituição, em termos de impacto no território, considera-se intangível, portanto fora do escopo desta análise.

O próximo aspecto a ser discutido, com base na estrutura da Figura 1, versa sobre a regulamentação de uma das categorias de UC, os Parque Nacionais (Parna), e de Instruções Normativas que orientam a criação de UC.

A primeira norma digna de menção é o Decreto no 84.017 de 21 de setembro de 1979, cuja temática central são os Parna. Essa norma descreve, aprofundadamente, as características que esse tipo de unidade de conservação deve possuir. Nesse sentido, assevera o caráter de proteção integral, com permissão tão somente de atividades de uso indireto dos recursos naturais e com menção expressa de um rol de proibições. Determina também um zoneamento a ser aplicado na área interna do Parque a fim de orientar o uso e a ocupação das atividades de lazer e pesquisa permitidas. O decreto em análise, apesar de não ser recente, ainda vige e explicita de forma muito precisa as determinações do uso do território. Por esse motivo, reveste-se de caráter imediato ao transformá-lo e impactá-lo.

A Lei nº. 6.902/1981 e o Decreto nº 99.274/1990 tocam em assuntos similares: a criação de Estações Ecológicas (ESEC) e as Áreas de Proteção Ambiental (APA). Esse assunto é pouco explorado no decreto, porém é o principal mote da lei. Não por coincidência, o teor da matéria é bem similar nos dois normativos. Em suma, ESEC é de proteção integral, por conseguinte, segundo a Lei no. 6.902/81, 90\% ou mais de sua área devem ser destinados única e exclusivamente para a preservação integral da biota; no restante da área, poderá ser autorizada a realização de pesquisas. Também é bem incisiva a determinação de que, nas áreas vizinhas a essa unidade, serão observados cuidados especiais para não afetar a biota interna. Além disso, tal como a norma concernente aos parques, há expressa menção a uma série de proibições de uso do território no interior desse tipo de unida- 
de. No tocante às APA, a norma é bem menos extensiva e apenas afirma que o órgão gestor irá emitir regramento para alguns tipos de uso que poderão ser incompatíveis com a conservação da biodiversidade, tais como a instalação de atividades poluidoras e a construção de obra que possam causar impacto ambiental ao solo e aos recursos hídricos. Mais uma vez, visto que se trata de normas que especificam os usos do território de diferentes tipos de unidades de conservação, podem ser classificadas como de impacto imediato.

Parte-se agora para as Instruções Normativas (IN) do ICMBio nº 3, 5 e 7. A de número 3 diz respeito aos requisitos que devem ser seguidos para se criar uma Resex ou uma RDS. Como esses dois tipos de unidades de conservação têm a prerrogativa de serem criadas a partir de demanda de populações locais ou tradicionais; o fluxo de sua criação e funcionamento guarda peculiaridades. A solicitação deve ser encaminhada pela população tradicional e recepcionada pelo ICMBio. Essa instituição deve proceder a toda a instrução processual para a UC ser criada, com destaque para a consulta pública, após concluído os estudos, como etapa primordial. Esse requisito é um dos motes da IN no 5 . Merecem realce o artigo $8^{\circ}$ da IN 5 e o artigo $13^{\circ}$ da IN 3. Em ambos os dispositivos citados, resta incontroverso o propósito da consulta: informar as populações afetadas sobre os estudos e coletar mais subsídios para a delimitação da UC. Especificamente na IN n ${ }^{\circ}$, a redação da norma é taxativa com relação à exigência de consulta pública, a qual deve indicar, de modo claro e em linguagem acessível, as implicações da criação da UC para a população residente no interior e no entorno da unidade proposta.

Ressalta-se, mais uma vez, que as consultas públicas são instrumentos condicionantes imprescindíveis, por meio dos quais a população local afetada pela UC toma ciência dos impactos de sua criação. Presume-se que, após a sua realização, pode-se promover a regressão de usos do território exploradores dos recursos naturais. Esse é um reforço à pista destacada em linhas anteriores que ajuda a explicar a contradição entre a redução da taxa de desmatamento e a condição vulnerável das UC no Brasil.

Em suma, essas IN ( $n^{\circ} 3,5$ e 7 ) são de caráter mediato na transformação do território pelo fato de serem definidoras apenas do rito a ser cumprido para a criação da UC, excetuando-se os dispositivos atinentes às consultas públicas.

A análise do território normado da política pública de UC traz a lume o tema dos planos de manejo. Esses planos são a base para a gestão das UC e indicam ao gestor da unidade e à população local onde podem ocorrer usos e não usos do território. É por meio desse documento que se verifica a eficiência da gestão das UC. É possível afirmar que boa parte da essência do conteúdo da forma está nos planos de manejo. 
De modo geral, esse tema não é coberto por uma estrutura legal, mas sim por roteiros metodológicos que orientam a elaboração dos planos de manejo. Estão contemplados por esses roteiros as RPPN, as Flonas, os Parnas, as Rebio e as Esec. A IN ICMBio no 1 detalha a metodologia que deve ser seguida para a construção do plano de manejo participativo de Resex e RDS. Essa IN traz pormenores sobre os estudos necessários para subsidiar a criação das UC e indica a necessidade, dadas as características específicas das UC, de construção participativa do plano.

Os roteiros seguem linha similar à IN descrita supra. Orientam a elaboração do plano. Em síntese, o conteúdo desses roteiros apresenta três momentos claros: diagnóstico da situação atual, zoneamento de usos e planejamento. Embora os planos sejam a essência da forma, esse conjunto de orientações não pode ser classificado como de impacto imediato, por ter caráter apenas orientador; não tem força de lei; não altera a forma ou indica conteúdos da forma. São de caráter mediato por servirem de base para a elaboração do documento.

O próximo aspecto a ser discutido em termos de impacto territorial é referente aos conselhos das unidades. Na figura 1, destacam-se as IN ICMBio no 11 e 2. No entanto, no final de 2014, essas duas IN foram revogadas, e esse assunto passou a ser regrado pela IN ICMBio nº 9/2014. É ela que será analisada a seguir.

A IN no 9/2014 trouxe algumas novidades para essa matéria no SNUC. Entende-se que a constituição dos conselhos, independentemente de seu caráter deliberativo ou consultivo, é um dos grandes focos de alteração do território após a criação de uma UC, pois esse fórum é essencialmente congregacionista de atores interessados no território. Não por acaso, a IN institui como etapa para se constituir um conselho a caracterização do território em que a UC está inserida. O propósito é realizar um mapeamento dos "setores usuários e dos setores reguladores dos usos do território", além de permitir identificar "as principais ameaças e potencialidades para a sua implementação, sobreposições territoriais, conflitos existentes e potenciais".

Por isso Mendonça; Talbot; Macedo (2014) afirmam que há uma expectativa de os conselhos serem o fórum, por excelência, de articulação das políticas públicas no território. Também está explícito que os conselhos acumulam o papel de gestão de conflitos territoriais. Assim, a IN trata dos seguintes temas: etapas e atividades de formação dos conselhos; instituições representativas dos setores no conselho; documentos para formalização dos conselhos; instalação do conselho e posse dos conselheiros; reuniões; e modificação do quantitativo e dos setores. 
De modo geral, parte do conteúdo dessa IN tem impacto imediato no território a partir da criação de uma UC pelo fato de os conselhos serem atos contínuos à criação e serem instâncias necessárias para acompanhamento e aprovação dos planos de manejo.

Outro aspecto que afeta legalmente as UC são os mosaicos de áreas protegidas. Os mosaicos estão previstos no SNUC e têm por objetivo operacionalizar a gestão integrada ou compartilhada de um conjunto de unidades de conservação de diferentes categorias e de outros tipos de áreas protegidas próximas territorialmente. A instituição de mosaicos implica a criação de conselhos consultivos como instâncias integradoras da gestão dos diversos fragmentos de áreas protegidas. A Portaria MMA nº 482 define procedimentos e critérios para reconhecer mosaicos. Até o ano de 2015, o MMA já reconheceu 13 mosaicos ${ }^{6}$.

Em suma, a Portaria é de efeito mediato no território, pois o mosaico não cria formas, porém busca integrar ações. Eventualmente, novas ações emergem do ato de se reconhecer mosaicos, contudo são coadjuvantes nas ações afetas a cada UC.

Os próximos temas dizem respeito às interferências externas que afetam as UC, ou seja, de fora para dentro. Segundo Raffestin (1993), em seu esforço para exemplificar como funciona o campo de forças e poder que atuam no território, é possível afirmar que, quando se instala uma UC, alguns vetores de poder sofrem retração e outros surgem, de modo que se altera a configuração de poder do território.

Segundo esse autor, "o poder é parte intrínseca de toda relação" (RAFFESTIN, 1993, p. 52). Afirma também que "o poder visa o controle e a dominação sobre os homens e sobre as coisas. Pode-se retomar aqui a divisão tripartida em uso na geografia política: a população, o território e os recursos" (Idem, p. 58). É interessante notar que dentre essas três categorias o autor ressalta que "o território é o espaço político por excelência, o campo de ação dos trunfos" (Ibidem, p. 60).

Tendo esse entendimento como base $e^{7}$, é possível afirmar que a implantação de uma UC no território promove um rearranjo de forças e poderes, cuja configuração irá pender para algum dos lados das relações. O próprio Raffestin (1993) afirma que existe o poder com 'p' maiúsculo e o poder com 'p' minúsculo. O primeiro manifesta-se "por intermédio dos aparelhos complexos que encerram o território, controlam a população e dominam os recursos" (Ibidem, p.52). Esse poder é claramente vinculado, entre outros, ao Estado ao tomar a decisão de implantar ou não uma UC em determinado território. No entanto, o autor traz à tona o poder que cada pessoa possui ao admitir que "há uma in-

\footnotetext{
${ }^{6}$ http://www.mma.gov.br/areas-protegidas/acoes-e-iniciativas/gestao-territorial-para-a-conservacao/mosaicos. Acessado em 29/03/2016. 7 Não se ignora que a temática concernente a poder e território é muito mais vasta do que o apresentado nesse artigo. Contudo, fugiria ao seu propósito discorrer longamente a esse respeito.
} 
finidade de campos de poder num sistema social em razão da multiplicidade de relações possíveis" (Ibidem, p. 64).

As normas a seguir, segundo a Figura 1, regem as atividades de turismo, a realização de estudos para averiguar o potencial de energia elétrica contida na UC, as concessões florestais, o licenciamento ambiental e suas compensações, as infrações/penalidades e os serviços voluntários. Todas as atividades que se originam externamente à UC e que, em certa medida, influenciam-na.

Cabe, primeiramente, fazer uma correção na Figura 1: a IN/ICMBio n ${ }^{\circ}$. 10, de 18/09/2008, deve ser substituída pela IN/ICMBio no 10, de 20 de maio de 2010, complementada pelo Decreto $\mathrm{n}^{\circ} 7.154$, de 9 de abril de 2010. São essas duas normas que regem o assunto da realização de estudos técnicos sobre potenciais de energia hidráulica e sobre a viabilidade técnica, socioeconômica e ambiental da instalação de sistemas de transmissão e distribuição de energia elétrica em UC. Em resumo, as normas orientam como deve ser o procedimento para realizar as duas atividades destacadas. São atividades relacionadas aos sistemas de engenharia ${ }^{8}$ que povoam o território e que, eventualmente, precisam acessar a UC, dado que ocupam um território vasto.

Em regra, essas atividades devem ser precedidas de autorização e devem causar o menor impacto possível no meio ambiente. Cabe destacar que não há necessidade de autorização para as APA e RPPN reforçando o caráter permissivo da primeira e a condição privativa da segunda. Assim, pode-se afirmar que essas duas normas são de impacto mediato, pelo fato de orientarem como devem ser os estudos e o fluxo burocrático de tal empreitada.

As outras duas IN constantes no rol relativo à exploração de bens e serviços das UC dizem respeito às atividades de visitação e ao uso de imagens. São elas a IN/ICMBio no 8 , de 18/09/2008 e a IN/ICMBio no 19, de 16/09/2011, respectivamente. Ambas as atividades são controladas pelo gestor da UC. É recomendado ao visitante que utilize serviços de condutores para a segurança e o pleno gozo do lazer, porém não é obrigatório. Para os casos de lugares que ofereçam risco ou exijam pernoite dentro da UC, os serviços de condutores passam a ser obrigatórios. Essa atividade é uma das que mais geram repercussões econômicas para comunidades locais, a depender do tipo de UC. O caso do Parque Nacional da Chapada dos Veadeiros é ilustrativo. Até a edição da IN/ICMBio no 8, o serviço de guia era obrigatório. Isso girava a economia para o povoado de São Jorge, distrito do município de Alto Paraíso de Goiás. Os guias, inclusive, constituíram uma associação pa-

8 Segundo Santos (1996), “[...] o homem foi, pouco a pouco, adicionando artefatos à natureza, modificando-a para criar verdadeiros sistemas de engenharia, bases da produção e do intercâmbio” (p.127). Esse meio geográfico atual, tecnificado pelos diversos sistemas de engenharia, foi denominado por Santos de meio técnico-científico-informacional. 
ra organizar melhor o atendimento ao turista. No entanto, após a edição dessa IN, o uso de guias foi reduzido, mas alguns ainda se mantêm na atividade.

Esse é um caso em que a norma será de impacto imediato ou mediato a depender do tipo de UC. Será imediato para os Parques Nacionais que têm maior apelo para a atividade de turismo. Para as Esec e Rebio, não há sequer possibilidade de enquadramento, ante o fato de essa atividade não ser permitida. E para aquelas em que a visitação é permitida, porém não é o seu principal mote, caracterizam-se como de impacto mediato, são os casos das APA, Aries, Resex, Flonas, Monumentos Naturais, Reservas de Fauna.

Já o uso de imagens da UC é regrado pela IN/ICMBio 19/2011. É importante diferenciar as imagens produzidas para fins de divulgação da UC. Esse tipo de promoção deve ser incentivada pelo gestor. Essa divulgação não se confunde com a promoção meramente comercial. Em anos anteriores, produziu-se uma campanha publicitária para uma determinada marca de carro utilitário no Parque Nacional dos Aparados da Serra no Rio Grande do Sul. Naquela ocasião, houve pagamento à UC para o uso comercial das imagens. Mais uma vez, cabe registrar que são interesses externos que visam explorar as belezas naturais da UC. A IN/ICMBio no 19, de modo geral, define como deve ser o trâmite para o uso de imagens da UC com fins comerciais. Pode-se considerar que é uma norma de impacto mediato no território pelo fato de não proibir esse tipo de uso e sim auferir recursos para a gestão da UC.

Ainda constam no rol de normas sobre a exploração de bens e serviços a Lei $n^{\circ} .11 .284 / 2006$ e o Decreto no 6.063/2007 que instituíram a política de concessão florestal. Essas normas foram citadas pelo fato de as concessões florestais poderem ocorrer nas Florestas Nacionais, Estaduais e Federais. Em síntese, as concessões florestais visam a delegar, por meio de outorga onerosa, a exploração, com técnicas de manejo sustentável, de recursos madeireiros presentes em florestas públicas ou Florestas Nacionais.

As concessões florestais são consideradas pelos especialistas como uma alternativa para o corte ilegal de madeira nobre da floresta, bem como uma maneira de reduzir o desmatamento. Essa política, então, tem interface com o SNUC, em virtude de envolver as Flonas. Segundo a Lei $n^{\circ}$. 11.284/2006 e o Decreto n 6.063/2007, toda concessão florestal interessada em explorar recursos da UC deve alinhar-se com as diretrizes do plano de manejo, deve ter autorização prévia do órgão gestor, deve ter oitiva do conselho consultivo e deve estar prevista na zona exclusiva de uso da comunidade local.

As leis também previram a possibilidade de as comunidades locais realizarem atividades de exploração dos recursos florestais. Porém, nesse caso, formaliza-se outro instru- 
mento, que não a concessão onerosa, denominado de termo de uso (normatizado pela IN/ ICMBio no 16/2011). Alguns dispositivos dessas leis vêm somar ao conteúdo da forma já previsto no SNUC. Em outras palavras, o SNUC define que um dos principais objetivos de uma FLONA é a exploração dos recursos florestais de modo sustentável pela comunidade autóctone. A lei da concessão florestal apenas detalha como essa exploração deve ocorrer dentro do âmbito mais amplo da política florestal brasileira. Dessa maneira, são normas de impacto mediato no território a partir da criação da UC.

Em continuidade à análise de fatores externos que interferem nas UC e são alvo de normas, o próximo aspecto refere-se ao licenciamento e à compensação ambiental.

A respeito do licenciamento ambiental, a criação de uma UC enseja algumas etapas a mais nesse processo, bem como algumas restrições à instalação de atividades potencialmente poluidoras. Cabe esclarecer que o licenciamento ambiental é um procedimento que visa a, seguindo o princípio da precaução, impor limites às atividades potencialmente poluidoras e evitar danos futuros irreversíveis ao meio ambiente. Como as UC são criadas utilizando o pressuposto da preservação/conservação de atributos biológicos ou paisagísticos importantes, deve-se ter maior cuidado na instalação de atividades que possam, porventura, causar danos a essas formas territoriais. Por isso, antes da instalação da atividade, deve ser consultado o órgão responsável pela sua gestão.

A Resolução n 237/1997 do Conama é a principal referência sobre o procedimento de licenciamento ambiental no Brasil. Não trata em nenhum momento sobre UC, mas traz definições importantes sobre o assunto. A partir dessa Resolução, foram publicados normativos que detalham como deve ser o licenciamento ambiental de atividades que se localizam nas imediações da UC, em sua Zona de Amortecimento, ou que possam afetar diretamente o interior dela. Mais uma vez, são vetores externos que podem comprometer ou alterar as condições primeiras da UC.

As IN/ICMBio no 4 e 5 e a Resolução/CONAMA nº 428 estabelecem procedimentos para autorização de tais atividades próximas às UC. Especificamente, a IN/ICMBio nº 4 abarca atividades que não são contempladas pelo licenciamento, mas que, localizadas na Zona de Amortecimento ou próxima a UC, precisam ser regradas. Em geral, esses três normativos afirmam que o conselho da unidade, o órgão gestor e o plano de manejo devem ser considerados no ato do licenciamento da atividade. A Resolução/Conama nº 428 traz um complemento afirmando que, no prazo de 5 anos, a partir da publicação desta norma, para as UC que não tiveram estabelecido suas Zonas de Amortecimento, deve-se considerar uma faixa de 3 mil metros a partir dos limites da UC para aplicar os regramentos da 
norma quanto às etapas do licenciamento.Também é interessante observar que nas APA e RPPN não se aplicam os dispositivos dessa norma, o que reforça o caráter de permissividade de uma e de privada da outra.

Essas três últimas normas analisadas (IN/ICMBio nº 4 e 5 e a Resolução/Conama 428) são de caráter imediato quanto às transformações no território, pois podem afetar usos e não usos no entorno das UC. Com relação à Resolução/Conama no. 237, que definiu o processo de licenciamento ambiental, deve-se classifica-la como de caráter mediato por não atingir diretamente o território das UC e seu entorno.

No tocante à compensação ambiental, cinco normas regem esse assunto, conforme explicitado na Figura 1: IN Ibama no 8 de 14/07/2011, IN/ICMBio nº 20 de 02/09/2009, Portaria/MMA no 416 de 03/11/2010, Portaria Conjunta nº. 225, de 30/06/2011 e Resolução/Conama n ${ }^{\circ}$. 371, de 05/04/2006. É importante lembrar que o tema da compensação ambiental está previsto no Art. 36 da Lei no 9.985/2000, na qual consta que todo "empreendimento de significativo impacto ambiental, assim considerado pelo órgão ambiental competente, com fundamento em estudo de impacto ambiental e respectivo relatório - EIA/RIMA, o empreendedor é obrigado a apoiar a implantação e manutenção de unidade de conservação do Grupo de Proteção Integral".

Assim, a primeira delas é a Resolução/Conama no 371/2006. Esse regramento estabelece diretrizes para o cálculo da compensação ambiental a ser aplicada aos empreendimentos. Um ponto importante a ser destacado diz respeito ao órgão ambiental licenciador que deverá indicar a ou as UC que irão receber recurso da compensação ambiental, e estabelece alguns critérios para isso: afetação da UC ou de sua Zona de Amortecimento pelo empreendimento; não atendendo o primeiro critério, então deve-se priorizar a criação de nova UC preferencialmente no mesmo bioma e na mesma bacia hidrográfica.

Essa função de apontar para onde os recursos da compensação deve ir foi avocada pelo Comitê de Compensação Ambiental Federal (CCAF), após a edição da Portaria Conjunta MMA/IBAMA nº 225/2011. Esse comitê elabora um rol de UC elegíveis prioritariamente para receber os recursos com base nos seguintes critérios: (i) fitofisionomia da área afetada; (ii) distância da UC em relação ao empreendimento; (iii) dimensão da UC; (iv) se a UC está integrada a um mosaico de Unidades; (v) se possui plano de manejo e conselho gestor; (vi) se tem reconhecimento internacional; e (vii) se o seu cadastro no CNUC está atualizado.

Uma vez escolhida a UC, o empreendedor é notificado para celebrar um termo de compromisso e execução da compensação ambiental. Ao empreendedor é facultada a pos- 
sibilidade de fazer o depósito do valor em conta corrente de banco indicado pelo ICMBio (IN/ICMBio no 20/2011) ou aplicar diretamente os recursos da compensação na UC indicada (IN/ICMBio no 10/2014, não contemplada pela Figura 1). Cabe destacar que, nos termos do Decreto $n^{\circ} 4.340 / 2002$, já analisado anteriormente, os recursos da compensação devem prioritariamente ser usados nas seguintes atividades da UC contemplada: regularização fundiária e demarcação das terras; elaboração, revisão ou implantação de plano de manejo; aquisição de bens e serviços necessários à implantação, gestão, monitoramento e proteção da unidade, compreendendo sua área de amortecimento; desenvolvimento de estudos necessários à criação de nova unidade de conservação; e desenvolvimento de pesquisas necessárias para o manejo da unidade de conservação e sua área de amortecimento.

Essas normativas analisadas sob a perspectiva territorial apontam que alguns vetores de ações relacionados ao meio ambiente devem ser originados de atividades relacionadas ao capital que promovam impacto ao meio ambiente. Em outras palavras, o território normado brasileiro, com o advento e fortalecimento das questões ambientais, tem impingido obrigações que devem fortalecer as UC e minimizar os impactos ambientais. De maneira geral, a Portaria Conjunta MMA/IBAMA no 225/2011 e a Resolução/Conama no 371/2006 são de impacto imediato no território em termo de fluxo de ação, porque impõe a obrigação de compensar, com a indicação expressa de sua compensação. As outras normas são definidoras do fluxo burocrático e documentação necessária para tal ato, e, por isso, não têm efeito sobre o território.

Embora não seja o foco desse artigo fazer uma análise entre o previsto em lei e a realidade, a título de curiosidade sobre a real situação da compensação ambiental no Brasil; a ONG The Nature Conservancy (TNC - Brasil) produziu um relatório que faz a análise do estado da arte da compensação ambiental no Brasil. Entre 2011 e 2014, foi destinado o montante de $\mathrm{R} \$ 1.090 .350 .165,87$ para esse fim. A explicação apontada para esse valor elevado está no fato de esses anos terem sido de grandes investimentos em obras de infraestrutura no país, da maior emissão de licenças ambientais, associados ao aperfeiçoamento do processo de destinação dos recursos da compensação (OLIVEIRA \& PINHEIRO, 2015).

Ainda segundo esse relatório, a Região que mais recebeu recursos da compensação foi a Sudeste, com 27\%; seguida do Norte (21\%); do Centro-Oeste (10\%); do Nordeste e Sul, ambos com 7\%. Além dessas regiões, também estão computados recursos destinados a critério do órgão gestor (28\%), os quais não necessariamente estão previstos para uma dada UC específica. A explicação para o Sudeste despontar está na concentração de empreendimentos ligados a petróleo e gás, ao passo que se justifica a posição do Norte em razão das obras de hidroeletricidade. Embora o montante seja expressivo, o mesmo re- 
latório destaca que ainda há uma diferença grande entre os recursos recebidos e os efetivamente executados, havendo necessidade de aprimorar a sua execução (Ibidem, 2015).

O próximo aspecto a ser analisado sobre o território normado das UC diz respeito aos normativos relacionados às penalidades, à gestão e aos incentivos para as UC. Sobre as penalidades ambientais, em geral, duas leis orientam as medidas de sanção, a Lei nº. 9.605/1998 e a Lei $n^{\circ}$. 6.514/2008. Essas duas leis tipificam os atos danosos ao meio ambiente e estabelecem um gradiente de penalidades a serem aplicadas ao infrator. As agressões praticadas contra as UC estão consignadas na Lei nº 9.605/1998, como espécie de agravante do ato lesivo. Em outras palavras, o ato lesivo ao meio ambiente praticado dentro de UC ou em suas imediações, com a produção de danos, é motivo para agravar a penalidade e, por conseguinte, ensejar a aplicação de sanções mais severas ao infrator.

Já a Lei no . 6.514/2008 traz uma subseção específica para crimes cometidos em UC ou em suas proximidades. Introduzir espécies exóticas, causar danos à biota, infringir o previsto no plano de manejo, entrar na UC portando instrumentos que podem causar danos à biota, entre outras, são ações que ensejam penas. As duas leis não têm um impacto imediato no território, mas reforçam os não usos já estabelecidos pela lei do SNUC. O somatório desses normativos, das consultas públicas que antecedem a criação da UC e das ações iniciais de fiscalização que são disparadas a partir da criação da UC ajudam a responder a contradição exposta na introdução desse artigo.

Por último, a IN/ICMBio nº 6/2009 detalha os procedimentos a serem seguidos para a apuração de infrações por atividades lesivas ao meio ambiente em UC. Tal como as outras, trata-se de uma norma orientadora e definidora de procedimentos com o intuito de apurar os fatos e aplicar penas ao infrator. Não implica novas ações ou na criação de formas no território. Por isso, em consonância com as outras duas leis, é de caráter mediato na transformação do território.

Em outro tema, a IN/ICMBio no 3/2009 estabelece o Programa de voluntariado do ICMBio adotando as diretrizes do Decreto no 4.519/2002. Esse programa institui critérios e visa a formalizar a atividade de voluntário na UC. De modo geral, essa IN tem impacto tangente no território, pois não cria formas nem emana novas ações, apenas normatiza uma força de trabalho que pode ajudar na implementação de ações na UC.

Nessa mesma linha, está o Decreto no 6.515/2008, que cria o Programa Guarda Ambiental Nacional e o Corpo de Guarda-Parques, e o Decreto 7.957/2013, que define a participação das Forças Armadas e da Força Nacional de Segurança Pública no apoio às ações ambientais. No primeiro caso, ambos os programas adotam a força de trabalho das po- 
lícias ambientais e corpo de bombeiros estaduais para amparar ações específicas nas UC por período determinado. $\mathrm{O}$ Corpo de Bombeiros irá se deter no combate às queimadas e na segurança da UC e a Guarda Ambiental Nacional em ações de fiscalização. O segundo caso é mais genérico e define como as Forças Armadas e a Força Nacional de Segurança Pública irão participar de ações relacionadas à proteção do meio ambiente. Tal como afirmado no parágrafo anterior, não são normas de impacto imediato ao território pelo fato de apenas reforçarem ações já pré-estabelecidas.

O penúltimo aspecto a ser tratado sobre o território normado das UC é denominado de consolidação territorial. Quando uma UC é criada, é bem provável que existam moradores e outros usos em curso no território. A depender do tipo de UC, é necessário retirar os moradores e suspender suas atividades. Nesse caso, é imperativo todo um processo para a incorporação da terra particular ou da terra ocupada à UC. Eis o motivo pelo qual recebeu o nome de consolidação territorial.

A IN/ICMBio no 2/2009 determina os procedimentos que devem ser seguidos para as desapropriações e indenizações cabíveis das benfeitorias construídas. Essa norma apresenta os critérios para as desapropriações e para as indenizações. Também orienta quais devem ser os documentos para tal procedimento. Já a Portaria SPU no 89/2010 “disciplina a utilização e o aproveitamento dos imóveis da União em favor das comunidades tradicionais, mediante a outorga de Termo de Autorização de Uso Sustentável - TAUS". Tal instrumento permite às comunidades locais ou a particular que façam uso tradicional do território sem causar impacto substancial à biota, de tal modo que se autoriza que continuem a habitar os terrenos constitucionalmente pertencentes à União. Nesse sentido, a portaria veda alguns tipos de atividades por entender que estão em desacordo com a definição de uso tradicional, como, por exemplo, atividades extensivas de agricultura, pecuárias ou outras formas de exploração ou ocupação indireta das áreas da União.

Em termos de impacto no território, pode-se dizer que essas duas normas produzem efeitos imediatos em razão de afetarem usos do território. Para efeito de exemplificação, quando se cria uma UC, usos pretéritos já ocorrem na área, ao menos que seja em algum lugar muito remoto. De todo modo, esse uso, em alguns casos, está em desacordo com a legislação e, conseguintemente, devem sofrer restrições ou serem extintos, afetando o território em sua dinâmica de ações. Tirante a parte processual das normas, a ação de desapropriação é uma interferência clara no território.

Por fim, e não menos importante, o território normado trata das populações tradicionais que habitam algumas das UC previstas no SNUC. Na verdade, a razão de ser das 
UC de uso sustentável é provar que existe sim a possibilidade de convivência harmoniosa entre o homem e a natureza, para além da apropriação capitalista tal como conhecemos. Ademais, também existe norma que regulamenta a permanência de população em UC que não permite a ocupação por moradores. Nesse sentido, cinco normas regram essa relação entre comunidades tradicionais e o meio ambiente em que vivem.

O Decreto n 6.040/2007 e a Lei 12.512/2011 são normativos que instituem ações do governo direcionadas às populações tradicionais, não necessariamente habitantes de UC. O decreto em apreço institui a Política Nacional de Desenvolvimento Sustentável dos Povos e Comunidades Tradicionais (PNPCT) e tem interface com o SNUC pelo fato de ter como um de seus objetivos específicos a solução e/ou minimização dos conflitos gerados pela implantação de UC de proteção integral em territórios tradicionais e de estimular a criação de UC de uso sustentável. Também prevê a elaboração dos Planos de Desenvolvimento Sustentável dos Povos e Comunidades Tradicionais como instrumento de implementação da PNPCT. Naturalmente, a criação de UC pode influenciar a convivência entre esses povos e comunidades. Já a referida Lei institui a Programa Bolsa Verde que objetiva incentivar a conservação dos ecossistemas e melhorar as condições de vida de populações vulneráveis. Seu público alvo é, dentre outros, famílias em situação de extrema pobreza que desenvolvam atividades de conservação em Florestas Nacionais, Reservas Extrativistas e Reservas de Desenvolvimento Sustentável federais.

Ambas as normas podem ser consideradas de efeito mediato, no tocante as transformações no território das UC, pois não criam forma e se somam a algumas ações que devem ser previstas nos planos de manejo.

As três IN/ICMBio que tratam do tema de populações tradicionais regulamentam os usos que estas últimas podem exercer nas UC. As IN/ICMBio n 26/2012 e 29/2012 estabelecem procedimentos para se firmar os Termos de Compromisso e os Acordos de Gestão entre o órgão gestor da UC e as populações tradicionais. Os Termos de Compromisso são utilizados para pactuar usos e não usos do território em UC de proteção integral no qual habitem populações tradicionais. A ideia é estabelecer regras para disciplinar a ocupação do território da UC, que estiver em desacordo com a lei, até que seja efetivada a remoção dos habitantes para outro local. Essa é uma norma de impacto imediato por afetar usos e não usos da UC e buscar alterar o conteúdo da forma criada. No mesmo quadrante, estão os Acordos de Gestão, pois esse é o principal instrumento de regulação do território de uma UC de uso sustentável. 
Por fim, a IN/ICMBio n 16/2011 estabelece diretrizes e procedimentos para a elaboração e a aprovação do Plano de Manejo Florestal Sustentável comunitário para exploração de recursos madeireiros no interior de Resex, RDS e Flonas. A partir desse documento, permitiu-se às comunidades habitantes explorar recursos madeireiros da UC. É uma ação direta que pode afetar a forma e cria conteúdo diferenciado à UC; nesse sentido, tal como as outras IN, é de efeito imediato nas transformações do território.

\section{CONCLUSÃO}

O território normado pelas UC é multifacetado. As políticas públicas e a legislação conexas apresentam interfaces com outras políticas públicas, o que torna a sua análise mais elaborada ante essa complexidade jurídica, socioeconômica e cultural diversa e interdisciplinar. Pretender tratar de todo o normativo que referencia uma política de tamanha envergadura exige um grande esforço de compilação. Não por acaso, ao longo deste texto, analisaram-se 54 normas sobre os mais variados assuntos.

No que diz respeito às transformações territoriais, destacam-se as normas que definem os tipos de UC e seus usos correlatos, o plano de manejo, os conselhos consultivos e toda a gama de ações que concernem à UC. É importante ressaltar que essa análise pode ser replicada para qualquer tipo de investigação relacionada ao território normado.

Duas últimas observações sobre essa empreitada: considerando que o Brasil é um país cuja tradição mostra a recorrência de tentativas de flexibilização das regras; considerando que essas regras são numerosas e de baixo conhecimento da população em geral; um complemento necessário a essa análise é cotejar o previsto em lei e a realidade de fato. Uma vez que se leve a cabo esse cotejo, tornar-se-á possível atestar, por completo, o impacto e as transformações de uma norma no território. Do contrário, permanecer-se-á no terreno das especulações e dos vaticínios.

Com relação ao paradoxo levantado na introdução, é possível afirmar que a contenção do desmatamento ou do uso pretérito à UC ostenta três explicações: as ações de comando e controle relacionadas à fiscalização; às normas que instituem penalidades; e as consultas públicas previstas em lei que informam a comunidade local sobre as consequências do ato de criação de uma UC no território. 


\section{REFERÊNCIAS}

3. BRASIL, Tribunal de Contas da União. Amazônia: unidades de conservação: auditoria coordenada/Tribunal de Contas da União. Brasília: TCU, 2014. http://portal2.tcu.gov.br/portal/ pls/portal/docs/2642553.PDF, acessado em 24/09/2015.

4. BRASIL, Ministério do Meio Ambiente. Áreas Prioritárias para Conservação, Uso Sustentável e Repartição de Benefícios da Biodiversidade Brasileira: Atualização - Portaria MMA $n^{\circ} 9$, de 23 de janeiro de 2007. Ministério do Meio Ambiente, Secretaria de Biodiversidade e Florestas. - Brasília: MMA, 2007. Disponível em http://www.mma.gov.br/estruturas/chm/_arquivos/ biodiversidade31.pdf

5. MENDONÇA, F.C \& TALBOT, V \& MACEDO, H.S. Reflexões sobre participação social em unidades de conservação e a contribuição do Instituto Chico Mendes de Conservação da Biodiversidade. In: BENSUSAN, N \& PRATES, A.P. (org). A diversidade cabe na unidade?: áreas protegidas no Brasil. Brasília: IEB, 2014. p. 269-307.

6. MORAES, A.C.R.Território na geografia de Milton Santos. São Paulo: Ed. Annablume, 2013.

7. OLIVEIRA, K.P. PINHEIRO, G.T. Compensação Ambiental. Um retrato sobre o cenário brasileiro. Brasília, The NatureConservancy - TNC, Brasil, 2015. Disponível em http://www. nature.org/media/brasil/compensacao-ambiental-retrato-cenario-brasileiro.pdf

8. PRATES, A.P \& SOUSA, N.O.M. Panorama geral das áreas protegidas no Brasil. In: BENSUSAN, N \& PRATES, A.P. (org). A diversidade cabe na unidade?: áreas protegidas no Brasil. Brasília: IEB, 2014. p. 82-120.

9. RAFFESTIN, Claude. Por uma geografia do poder. São Paulo: Ática, 1993.

10. SANTOS, Milton. Técnica, espaço e tempo: globalização e meio técnico-científicoinformacional. São Paulo: Hucitec, 1996.

11. _ . A Natureza do Espaço. Técnica e Tempo. Razão e Emoção. $2^{a}$ edição. São Paulo: Edusp, 2002.

12. SALMONA, Y.B; RIBEIRO, F.F; MATRICARDI, E.A.T. Parques "no papel” conservam? O caso do parque dos Pireneus em Goiás. Revista Goiana de Geografia, Goiânia, v.XXI, n.1, p. 67-82, jan-jun. 2009. Acessado em revistas.ufg.br/index.php/bgg/article/view/31740.

13. STEINBERGER, Marília (org.). Território, Estado e políticas públicas espaciais. Brasília: Ler Editora, 2013.

Artigo recebido em 11 de maio de 2016.

Artigo aceito em 09 de agosto de 2016. 